\title{
SOCIO-ECONOMIC FACTORS AND CROP PRODUCTION EFFICIENCY IN CHINA AND ETHIOPIA: A REVIEW
}

\author{
Tesema Feyissa $1,2 \bowtie(i D)$, Wakjira Gurmesa ${ }^{1,2}$ \\ ${ }^{1}$ China Agricultural University, College of Resource and Environmental Science, P. O. Box 100083, Beijing, \\ China. \\ ${ }^{2}$ Holeta Poly Technic College, Department of crop production, P.O. Box 11, Holeta, Ethiopia.
}

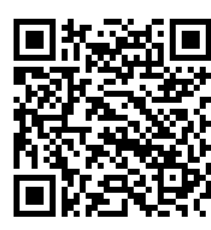

Received 4 November 2021

Accepted 15 December 2021

Published 31 December 2021

\section{CorrespondingAuthor}

Tesema Feyissa,

tesemafayyisaa@gmail.com

DOI

10.29121/granthaalayah.v9.i12.2021 .4431

Funding: This research received no specific grant from any funding agency in the public, commercial, or not-for-profit sectors.

Copyright: (C) 2021 The Author(s). This is an open access article distributed under the terms of the Creative Commons Attribution License, which permits unrestricted use, distribution, and reproduction in any medium, provided the original author and source are credited.

\section{ABSTRACT}

The main challenge of agriculture is to ensure food security in line with yield increases and minimize environmental costs due to complex interactions between social, economic, and ecological factors. Here we review to identify the impacts of socio-economic factors on crop production efficiency between China and Ethiopia. To set the economic reform and improve the grain yields in rural China, a series of policies on land reforms from communal systems to tax cancelation and subsidies have been implemented. Similar to China, Ethiopia has also experienced different types of land reform from landlord and peasant structure to land as the common property of nations, nationalities, and peoples of Ethiopia. The Gross Domestic Products per capita trends which represent the mean standard of leaving of residents in a country show almost similar growth in the 1980s while later significant variation was achieved between the two countries. It is suggested that to meet food security and increase agricultural efficiency in Ethiopia better infrastructure development that meets socio-economic demands should be prioritized while in China policies to reduce fertilizer inputs are highly recommended to minimize the environmental costs due to high agricultural inputs for sustainable agriculture growth.

Keywords: China, Ethiopia, Land, Crop Production, Food Security, GDP Per Capita

\section{INTRODUCTION}

Globally the world population is expected to grow about 9.7 billion by $2050 \%$ Nations United (2019). Agriculture is a broad term that refers to the interaction among people, plants, and animals in which the final target is the production of different products such as food, fiber, or raw material for industries Sihem (2019). The great challenge agriculture face is to ensure food security through enhancing yield and reducing the environmental costs because agriculture production systems are influenced by complex interactions between social, economic, and ecological factors which are sometimes difficult to integrate into a common analytical framework Chen et al. (2013), Chen et al. (2014), Nkurunziza et al. (2020). China has to feed $20 \%$ of the world's population with limited resources of about $7 \%$ of arable land and $5 \%$ of the planet's water resource Zhang (2011). Since the late 1970s, China's agriculture sector has changed dramatically and started to grow $5 \%$ annually in the past while significant growth has been seen in almost all cropping sectors and the production of some cereal crops has grown faster Huang et al. (2012) . China is strengthening its food self-sufficiency approaches and depending on large-scale 
imports from global markets to meet the huge demand for food in line with the growing population. China is facing many challenges to maintain its targeted grain self-sufficiency of 95\%, which loss of cultivable land, limited water resources, impacts of climate changes, frequent natural disaster, increased demand from population growth, vulnerable ecosystems, improved standard of living, and outdated agricultural infrastructure are the most prominent one Ghose (2014). The current farmer practice depends on high and unsustainable use of chemical fertilizer and plant protection chemicals, and irrigation water. Hence land resource is limited, further improvement in China's grain yield requires agriculture intensification by intensified land management and the introduction of a high level of technology. But currently, the intensified agricultural method also resulted in water shortages and pollution in China Ma et al. (2015), Mccartney and Lefsrud (2018) .

Agriculture growth productivity has been viewed for a long time as basis to the process of structural and economic growth, but productivity in agriculture remains low in most developing countries due to the relative inefficiency of agriculture may be as the consequence of frictions that produce a misallocation of socio-economic factor and productive resources Huang et al. (2017) , Chang et al. (2018). In recent years development practice in many African countries prioritized the formalization of socio-economic policies to enhance the better handling and use of an asset for socio-economic development Edwin et al. (2020) . For the most part, the highland of Ethiopia's settled agriculture is the dominant form of supporting livelihood from ancient times to till now since about $80 \%$ of the population live in rural parts of the country Kebede (2002) . Alemu et al. (2017) referred that agriculture is one of the key sectors in Ethiopia by serving about $85 \%$ of the total population placing the smallholder farmers as the main focus of the development and strategies, but it had been challenged by a slow growth rate estimate of about $1.4 \%$ per annum which was less than the growth rate of the population $2.49 \%$ during the last three decades. Ethiopia is one of the Sub-Saharan African countries that are facing an overwhelming challenge to achieve food security and sustainable rehabilitation of natural resource degradation base due to fast population growth and poor technological progress in agriculture finally leading to poverty. To solve the diversity of problems facing smallholder farmer investment priorities and policies must emphasize the resources they utilize, their choices of activities, the whole structure of their lives which are linked to biological, physical, economic, and cultural environmental factors in which they survive and over which they have limmited control FAO and World Bank (2001).

\section{THE SCOPE AND CONCEPTS OF SOCIO-ECONOMIC DEVELOPMENT}

Socio-economic development is in the socio-economic spheres which is any problem of change or the development functions as a product of optimistic vision and delivering of social interest, and a tool of analysis Chojnicki (2010). Impacts can be defined as the potential changes in whole or in the party for better or for worse caused directly or indirectly by industrial development activities Valley (2007).

\subsection{SOCIO-ECONOMIC COMPONENTS}

\subsubsection{LAND TENURE}

Land tenure is the ownership or access to an area of land which determines the relationship between responsibility and authority over land and natural resources which is an incentive structure for sustainable use and land conservation Industries 
and Conservation (2013). The fixed nature of land supply makes it unique from other factors of production because the land is physically the immobile resource and every plot of land is different from others in its economic potential status which implies that the value of land as the expected rate of return as a capital investment in agricultural production as well as financial security as wealth transfer across families and resource for consumption process Lohmar et al. (2009) .

Reform in land systems has been a key issue of transformation of China from a planned central command economy to a decentralized market economy which changes Chinese mostly rural and agricultural to an urban and industrial one. To set the economic reform in rural China the country implemented different policies and laws. China carried out collective farming that was characterized by collective ownership and unified collective action before the land tenure reform in 1978. Next, to collective ownership, the country implemented the Household responsibility System (HRS) from 1978 in which the landholding was distributed among households, and practically all rural households have had the land. Under the HRS framework, there are five main tenure types in China: responsibility land, grain ration land, contract land, private plot, and reclaimed land. Although these land tenures have different characters the underlying concepts behind the plan of the institution was to allow rural household freedom of productive choices and secure land use rights as a method of promoting individual investment, but collective village authorities restrict the ownership and remain in their hand and difficult to transfer the land between household Huang et al. (2017), Chang et al. (2018). Additionally, HRS is the collective ownership with private use in which agricultural land leftovers the collectively owned at the local level and economic agents creating an ambiguous institutional content for rural citizens since the local authorities have an influential role on land use and allocation Shi and Vendryes (2018) .

China's land-use systems are unique in which state-owned urban land and farmer collective-owned rural land are the two types of land ownership. According to rural land law, regulations favor agricultural use and development which is categorized into three major types of namely farmer residential plots, public facilities land use, and land use for the township or village enterprises. The reforms step by step leads to agriculture modernization which increased overall production, decreased hunger, and also change in social and environmental problems such as soil and water pollution, biodiversity loss, diet-related diseases, and food safety issues Day et al. (2017) , Huang et al. (2017) . The re-establishment of household production of agriculture autonomy and independent markets for agriculture products has been the first place toward a market-based economy and rapid economic growth in which the farmer becomes the first beneficiary. From collective ownership and work teams, HRS enables the farmer to shift labor and land efforts from grain to cash crops and animal production. Furthermore, grain production highly increased due to farmers' allocated resources being more efficient than central planners Lohmar et al. (2009) , Liu and Liu (2016). To secure the farmer and extend rights over their use different wave reforms was taken under HHS. According to 1984, the contract duration was extended to 15 years and rural land transfer rights are granted. Further, the second wave of reform also took in 1998 to establish secure rights in the long term for Chinese farmers Sun et al. (2019) . To increase the grain yield China developed the fast grain and fertilizer evolution in 1961-1978 communal systems, 1979-1987 household responsibility systems, 1988-1996 grain bag project and fertilizer subsidy, 1997-2003 market-driven fertilizer price and subsidy programs, and 2004-2015 tax cancelation and subsidy JIAO et al. (2020) .

Like China, Ethiopia has also experienced different types of reform on land. Land property rights in Ethiopia had been linked and shaped with socio-politico- 
economic relations and processes. Before the 1974 revolution, the country's land tenure systems varied across the region in which the northern farmer enjoyed land use rights as a landlord. The adopted land policy called rist systems (a public or kinship system where rights were usufruct and could not be reassigned and guly, a form of rights characterized by large estates approved to members of the aristocracy) had granted the northern and northwestern peasant the right to use the land. On the other hand, in the south, west, and eastern parts the majority of households worked as tenants of sharecropping for the northern landlord and local notables. The northern feudal systems evicted them from their land and restrict them to own land as their property rights. This implies that there were no standardized land tenure systems in Ethiopia until the overthrown of monarchy rule Deininger and Jin (2006), Bezabih et al. (2011) .

When the socialist Derg regime had overthrown the Haile Selassie of the imperial regime in 1975 the reform had altered the agrarian structure and the methods of access to land nationalized as all rural land set out to bring together farmers as cooperatives. The 1975 land tenure reform had characteristics of the land to the tiller in which landlordism and the tenants' systems were abolished but the reform had the character of state marketing quotas, cooperativization, and heavy tax burden. The Derg regime reorganized the land reform platform based on two principles; (1) historical justice- to end the exploitative character of imperial agrarian linkage and (2) justice as egalitarianism- to afford each farmer family with equal rights to use for cultivation land depending on their needs. Further farmers were restricted of rights by sale, mortgage, or lease and the maximum plot per family was restricted to 10 hectares Crewett et al. (2008), Hanjra et al. (2009), Reynolds et al. (2010), Kelly and Peluso (2015).

After the collapse of the military Derg regime from 1991 to 1995 the transitional government of Ethiopia declared the continuation of the former land policy. Then in 1995, the government state ownership of land was structured in the constitution. The Ethiopian People Revolutionary Democratic Front (EPRDF) had formulated the new policy in which the constitution of the country states that "land is the common property of nations, nationalities, and peoples of Ethiopia and shall not be subjected to sale or other means of exchange" which implies that both public and government had ownership rights over land. The government planned the state ownership policy to avoid cease the evection, unimportant urban-rural migration of then landless peasantry, and finally to protect the rural farmer from the negative impacts of market forces. Supplementary, the current government had started registration and land ownership certification for the rural communities to enhance the sense of ownership which enables the farmers to safeguard their lands for future use and conserve from degradation Crewett and Korf (2008a) , Crewett and Korf (2008b) , Deininger et al. (2008), Chekol (2017) .

\begin{tabular}{|c|c|c|c|}
\hline & Ownership & Contract rights & $\begin{array}{l}\text { Management rights and } \\
\text { responsibility }\end{array}$ \\
\hline China & $\begin{array}{l}\text { States in urban areas } \\
\text { and collective } \\
\text { ownership in the rural } \\
\text { areas. }\end{array}$ & Administrative village & $\begin{array}{l}\text { Units or individuals using land } \\
\text { shall be responsible for the } \\
\text { protection, management, and } \\
\text { rational use of the land. }\end{array}$ \\
\hline Ethiopia & $\begin{array}{c}\text { The state and people } \\
\text { of Ethiopia. }\end{array}$ & $\begin{array}{l}\text { Public and states } \\
\text { depending on the } \\
\text { duration of the } \\
\text { agreement }\end{array}$ & Public and government \\
\hline
\end{tabular}




\begin{tabular}{|c|c|c|}
\hline & $\begin{array}{l}\text { Advantage of current land tenure } \\
\text { on crop yield }\end{array}$ & $\begin{array}{c}\text { The disadvantage of current land tenure } \\
\text { on crop yield }\end{array}$ \\
\hline China & $\begin{array}{c}\text { Easy for the application of } \\
\text { technologies and natural resource } \\
\text { management. }\end{array}$ & $\begin{array}{l}\text { Instability of the peasants' land use rights and } \\
\text { insecurity of income right above weaken } \\
\text { peasants' enthusiasm for investment inland. }\end{array}$ \\
\hline Ethiopia & $\begin{array}{l}\text { Easy for farmers to make long-term } \\
\text { investment decisions on land and to } \\
\text { adopt the best cropping system. }\end{array}$ & $\begin{array}{l}\text { Restricted for farmers to use the land as } \\
\text { collateral for credit for agricultural } \\
\text { investment and adaptation of modern } \\
\text { technology. }\end{array}$ \\
\hline
\end{tabular}

\subsubsection{LAND FRAGMENTATION AND SIZE OF HOLDING}

Farmland is one of the key resources for human existence and development, nevertheless, in many parts of the world farmland fragmentation has become a serious problem leading to both ecological damage and economic loss due to low crop production efficiency. Land fragmentation can be defined as the condition in which a single farmer or owner consists of many spatially separated plots or farmers utilizing two or more geographically separated parcels of land, by taking account of the distance between those tracts Alemu et al. (2017). Thousands of years to meet the needs and aspirations of the growing population agriculture activities depend on farmland expansion as larger terrestrial ecosystems, but starting from the 1960s to meet the growing population food demand agricultural technology has been improved and recently there is the global reduction of total farmland due to human activities such as occupation (the substitution of farmland) by infrastructure development like road and urbanization which cause physical fragmentation of farmland landscape Heerink et al. (2007), Cheng et al 2015)

Hristov (2009) reported that land fragmentation is caused by two factors called supply-side which reflects an exogenous farmers imposition of a pattern of land areas due to inheritance laws, population pressure, and scarcity of land while demand-side causes refer to the varying degree of fragmentation selected by the farmer to minimize the risk of natural disasters such as droughts, floods, and fires and to encourage crop diversification and to ease allocation of labor over cropping seasons. Agricultural land fragmentation has both positive and negative impacts on farmers' productivity. The positive factors include such as increasing biodiversity society's economic value of the landscape, creating a big opportunity for risk diversification but also minimizing at a farm level because the fragmented farm is less exposed to the outbreak of pests and diseases spreads. In controversy, fragmented land has negative impacts on farmer yield and economic value such as creating additional farmer field trips which result in additional road works, road safety issues, and greenhouse emissions, it affects farmer performance by affecting farmer production decisions during labor allocation on-farm through causing conflicts and disputes. It increases production cost due to additional equipment requirement, and /or external service expenses secondary farm building and finally, it can also limit management practices especially in terms of herd management and brings high investment cost on soil quality improvement such as on drainage activities highly hence it reduces the area of small plots leading yield reduction Latruffe and Piet (2014), Ali et al. (2019), Dong et al. (2020) .

In China, during the past few decades, land reform has created a fragmented agricultural land structure leading many individual farmers to have several small fields with distant locations. The fragmented land had affected the labor supply, technology in machinery use Lai et al. (2015). Agriculture growth in China is 
commonly an obstacle by land fragmentation, and the land fragmentation is due to a large extent to the egalitarian philosophy applied in sharing and reallocation of land use rights to the household. The land is classified into different classes with each household receiving land from different land classes. Additionally, the land is dependent based on household size implying that large households receive significantly more and bigger plots than smaller households. Further landholding in suburban areas is highly fragmented may be due to farmers cultivating and growing high-value-added crops in these areas Tan et al. (2006) ,Dong et al. (2020) . Jia and Petrick (2014) referred that liberal land policies and less fragmented land is key steps of encouraging general productivity by enhancing the features of the economic scale, especially the adoption of agriculture machinery in line with farm labor availability.

China has many shared common issues with other emerging and developing countries like Ethiopia such as broad land fragmentation in highly smallholderbased farming systems Sun et al. (2018). Belay and Manig (2004) found that state ownership in Ethiopia has led to smaller and fragmented landholding at the individual level which in turn resulted in the cultivation of marginal lands. Currently, limited off-farm employment opportunities, and growing population pressure, state ownership of land tenure makes farmer agriculture simply a refuge for the rural population. Additionally, the current state ownership land tenure restricts the right incentives to enterprising farmers and also does not reflect a policy direction on the government part since the government is not committed to build a free market economic system. The research conducted in southern part of Ethiopia found that land fragmentation has leads to many problems in the local areas such as higher costs leading to less efficiency, increase border disputes resulting loss of land as a demarcation purpose and erosion control, hinder investment in the land like integrated soil and water conservation measures to enhance the soil fertility, requires the spatial disintegration of plots to multiple and separate parcels and also minimize the number of alternative use of remote plots Cholo et al. 2018.

In Ethiopia, in most of the highland and lowland regions, more than 69\% of parcels were acquired through inheritance from local officials. Particularly in highland areas land is obtained from local leaders as the primary method of acquiring land while in lowland areas there was little redistribution due to low population density. However, in pastoral areas of the Afar and Somali region, most of the plots are obtained from local leaders and inheritance but about $27 \%$ are acquired attained without permission leading to land fragmentation Knippenberg et al. (2017). Currently, in Ethiopia smallholder agriculture is featured by high small farms fragmented into multiple plots and too small to meet the food subsistence needs hence large families are relying on labor-intensive methods of cultivation. Likewise, research finding in Northern Ethiopia Gojam indicates that the majority of the farmer had three to five parcels of the cultivable plots Gajendra and Niroula (2005) , Paul and Gĩthĩnji (2017).

Table 3 The advantages and disadvantages of land fragmentation on crop and nutrient use efficiency

\begin{tabular}{|c|c|c|c|c|}
\hline & $\begin{array}{l}\text { Advantage of } \\
\text { current land } \\
\text { size on crop } \\
\text { yield }\end{array}$ & $\begin{array}{l}\text { Advantage of } \\
\text { current land size } \\
\text { on nutrient use } \\
\text { efficiency }\end{array}$ & $\begin{array}{l}\text { The disadvantage of } \\
\text { current land size on } \\
\text { crop yield }\end{array}$ & $\begin{array}{c}\text { The disadvantage of } \\
\text { current land size on } \\
\text { nutrient use } \\
\text { efficiency }\end{array}$ \\
\hline China & $\begin{array}{l}\text { Increasing } \\
\text { crop rotation } \\
\text { flexibility. }\end{array}$ & $\begin{array}{l}\text { Agro diversity } \\
\text { and agricultural } \\
\text { intensification }\end{array}$ & Increase labor cost & $\begin{array}{l}\text { Restricts the } \\
\text { maximum volume of } \\
\text { produce the }\end{array}$ \\
\hline
\end{tabular}




\begin{tabular}{|c|c|c|c|c|}
\hline Ethiopia & $\begin{array}{l}\text { Reduce risks } \\
\text { of flooding, } \\
\text { diseases, and } \\
\text { output } \\
\text { variation }\end{array}$ & $\begin{array}{c}\text { Multi and } \\
\text { rotational } \\
\text { cropping }\end{array}$ & $\begin{array}{l}\text { Dispute increased, } \\
\text { mechanization and } \\
\text { new technology } \\
\text { difficult for } \\
\text { application, and land } \\
\text { loss due to }\end{array}$ & $\begin{array}{l}\text { Hinder investment in } \\
\text { the land like } \\
\text { integrated soil and } \\
\text { water conservation } \\
\text { measures to enhance } \\
\text { the soil fertility }\end{array}$ \\
\hline
\end{tabular}

\subsubsection{LAND CONSOLIDATION AND OPERATIONAL EFFICIENCY}

Land consolidation can be defined as an interchange of individual ownership and location spatially isolated tracts of farms to make new ownership containing a single (as few as possible) parcel(s), with a uniform value of land as original areas which can be done from voluntary to compulsory Zhang (2016). The ultimate goal of land consolidation is to address socio-economic governance, minimize land fragmentation, increase grain yield capacity, promote land tenure transfer, and encourage agricultural operational scale. The LC is a complex work requiring land leveling, village modification, farmland irrigation structure, improvement of the road network, land tenure transfer, agricultural landscape, natural resources, and finally to meet sustainable development in rural areas Zeng et al. (2018) . In China, the beginning of and development of land consolidation is linked to a crucial land policy termed Balance of Farmland which means that occupied farmland for development of urban must be substituted by equal area and quality of farmland Zhang (2016), Zeng et al. (2018) . Starting in the mid-1990s China has launched different land consolidation projects that target the development and consolidation of scarred land for supplementing cultivated land as well as the integration of field, water, roads, forest, and village that finally leads the overall development of urban and rural areas. The previous emphasis of enlarging the area of cultivable land is transformed to wide-ranging management containing quantity control, quality management, and ecological management Yan et al. (2015), Yang et al. (2020). In China land consolidation should be divided into four stages: national, provincial, municipal, and county level as shown in Figure 1.

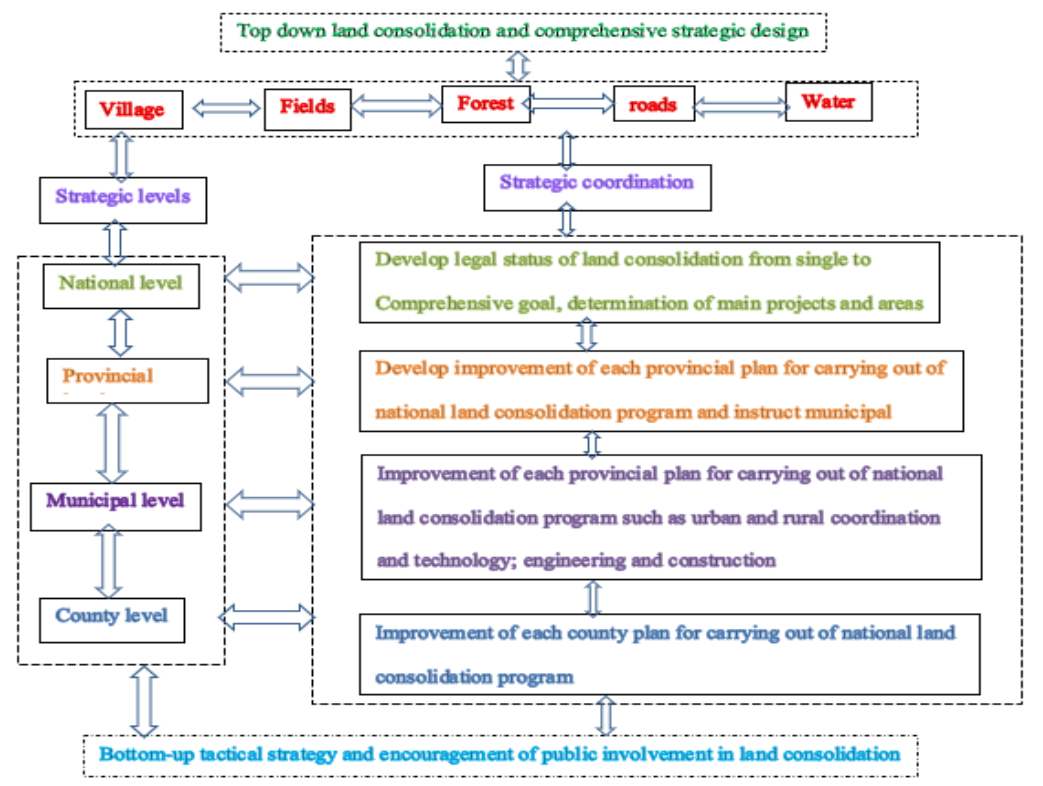

Figure 1 Land consolidation strategy in China. Source: author adopted from Yan et al. (2015), Zhang et al. (2018) 
Land consolidation in developing countries like Ethiopia has a significant role in agricultural mechanization, improves labor productivity, enhances transport facilities, better utilization of farm resources, reduces cost, and enhances opportunities for private investment. Different projects have been doing to meet the voluntary land consolidation in Ethiopia for the last two decades Gedefaw et al. (2019) stated that $68 \%$ of landholder farmers are highly volunteering to participate in land consolidation whereas a few shows unease with voluntary land consolidation. Furthermore, the author highlighted the determinants that influence voluntary land consolidation:(1) that should better happen with parcels of neighbors, (2) land consolidation should be arranged in better ways, (3) nearness of plots to be farmsteads, and (4) expected to improve the productivity. According to Gedefaw et al. (2019) in developing countries like Ethiopia policy to encourage land consolidation is required for social, economic, and environmental factors Table 1.

\begin{tabular}{|c|c|}
\hline Reason type & Explanations \\
\hline Social & $\begin{array}{c}\text { To reduce the disagreement between neighbors farmers to develop good } \\
\text { teamwork. }\end{array}$ \\
\hline Economic & To enhance production and enable self-sufficiency in food security. \\
\hline Environmental & $\begin{array}{c}\text { To improve soil quality, protect water availability, and balance climatic } \\
\text { conditions. }\end{array}$ \\
\hline
\end{tabular}

Source author adapted from Gedefaw et al. (2019)

Table 5 Advantage and disadvantages of current landconsolidation between China \& Ethiopia

\begin{tabular}{|c|c|c|}
\hline & $\begin{array}{l}\text { Advantage of current land consolidation } \\
\text { on crop yield }\end{array}$ & $\begin{array}{l}\text { The disadvantage of current land } \\
\text { consolidation on crop yield }\end{array}$ \\
\hline China & $\begin{array}{l}\text { Reduced cost of manual labor, increase } \\
\text { the cultivable land quality. }\end{array}$ & $\begin{array}{l}\text { Removal of the farm from a concentrated } \\
\text { village area to other places }\end{array}$ \\
\hline Ethiopia & $\begin{array}{l}\text { Increase investments in agricultural } \\
\text { inputs in the form of chemical fertilizers } \\
\text { and infrastructures for irrigation. }\end{array}$ & $\begin{array}{c}\text { Land consolidation project depends fully } \\
\text { on the authority charged with the } \\
\text { execution of the scheme leading to } \\
\text { bureaucracy }\end{array}$ \\
\hline
\end{tabular}

\section{GROSS DOMESTIC PRODUCT AND POPULATION OF CHINA AND ETHIOPIA}

The size of the population is a key factor of economic growth by determining the supply of human resources. The skilled labor proportion to human resources has a high influence on one nation's economy. There is no common consensus on population growth and economic growth whether it is beneficial or detrimental and the debate is going. Population growth has positive impacts such as enlarging the domestic market for the economy, encouraging competition towards innovation and technological advancement. However, large population growth has negative impacts on food security achievement, saving developments, and foreign exchange Shen (2015), Peterson (2017).

According to an online World Bank data report, the total population of China was about 1 billion people while Ethiopia's population was about 40.8 million population in the 1980s Table 6. Even though the population of China was high in the 1980s and the percent increase shows a low rate of population growth which 
are $14.3 \%, 24.5 \%$, and $30.6 \%$ from the 1990 s to 2010 s while Ethiopia population growth rate shows a more than double increase within four decades (percent increase of $37.1 \%, 85.3 \%$, and $147.2 \%$ from 1990 s to 2010 s) Table 6 . According to FAO, 2018 the urban population of China is higher than the rural one. The urban population accounts for about $59.7 \%$ while the rural population is $40.3 \%$ of the total population. Controversy to China FAO, 2018 indicates the rural population of Ethiopia is significantly higher than the urban population accounting for $20.8 \%$ and $79.2 \%$ for urban and rural respectively.

The Gross Domestic Products of Ethiopia was about 9.5 billion USD in the 1980s and shows a reduction of $3.4 \%$ in the 1990 s probably due to the collapse of the military Derg regime and the rise of Ethiopia Revolutionary Democratic Fronts which results in instability and the government structural changes. Later on, in the last two decades a substantial increase of $58.3 \%$ and $543.7 \%$ in the 2000 s and 2010 s Table 6. The Gross Domestic Products of China 1980s illustrates 231.9 billion and the GDP of China starting from the 1980s indicates significant growth by $203.4 \%$, $1,012.8 \%$, and $4,433 \%$ from the 1990 s to 2010 s which is a relatively very huge amount of growth from decades to decades.

\begin{tabular}{|lcccc}
\hline \multicolumn{5}{l}{ Table 5 GDP and population of China and Ethiopia } \\
\hline Year & $\begin{array}{c}\text { China GDP } \\
\text { (Billion \$) }\end{array}$ & $\begin{array}{c}\text { Ethiopia GDP } \\
\text { (Billion \$) }\end{array}$ & $\begin{array}{c}\text { China Population } \\
\text { (million) }\end{array}$ & $\begin{array}{c}\text { Ethiopia Population } \\
\text { (million) }\end{array}$ \\
\hline $1980 \mathrm{~s}$ & 231.9 & 0.2 & 1043.3 & 40.8 \\
\hline $1990 \mathrm{~s}$ & 702.9 & 0.7 & 1193 & 56 \\
\hline $2000 \mathrm{~s}$ & 2580 & 2.6 & 1299 & 75.7 \\
\hline $2010 \mathrm{~s}$ & 10510 & 10.5 & 1363 & 100.9 \\
\hline
\end{tabular}

Source: author computed from online World Bank data

\section{GDP PER CAPITA AND ANNUAL GROWTH RATE OF CHINA AND ETHIOPIA}

Gross Domestic Products (GDP) is the measurement of the monetary value of final goods and services which are produced in an economic boundary brought by the final user in a given period. Real Gross Domestic Products (GDP) per capita is a representation of the mean standard of leaving of residents in an area or a country. Positive percent change in annual real GDP per capita shows an improvement in the mean standard of living of the residents in a country Shen (2015), Maestas et al. (2016), Peterson (2017), OECD (2019).

The Gross Domestic Products per capita trends of China and Ethiopia show slow growth until the 1980s decades. The China GDP per capita was about 249.4 USD in the 1980s and shows a percent increase of $127.4 \%, 694.1 \%$, and 26478.4 from the 1990s to 2010s respectively (Figure 2 a). China's GDP per capita of 10,261.7 USD (2019) is relatively low in comparison to other developed countries like the USA $(65,297.5$ USD,2019) and others due to a large number of populations 1.39 billion (World Bank). In the 1980s Ethiopia and China's GDP was almost similar which was about 230 USD. Nevertheless, Ethiopia's GDP per capita shows a reduction for two decades by $32.3 \%$, and $7 \%$ in the 1990 s and 2000 s decades while in the 2010s the GDP per capita of the country shows a significant increase of $145.4 \%$ (Figure $2 \mathrm{~b}$ ). China annual growth rate were about 5.7\%, 11.2\%, 16.1\%, and $10.5 \%$ while the Ethiopia annual growth rate were $2.4 \%, 3 \%, 8.7 \%$, and $9.5 \%$ from 1980 s to 2010 s (Figure 2 b). 

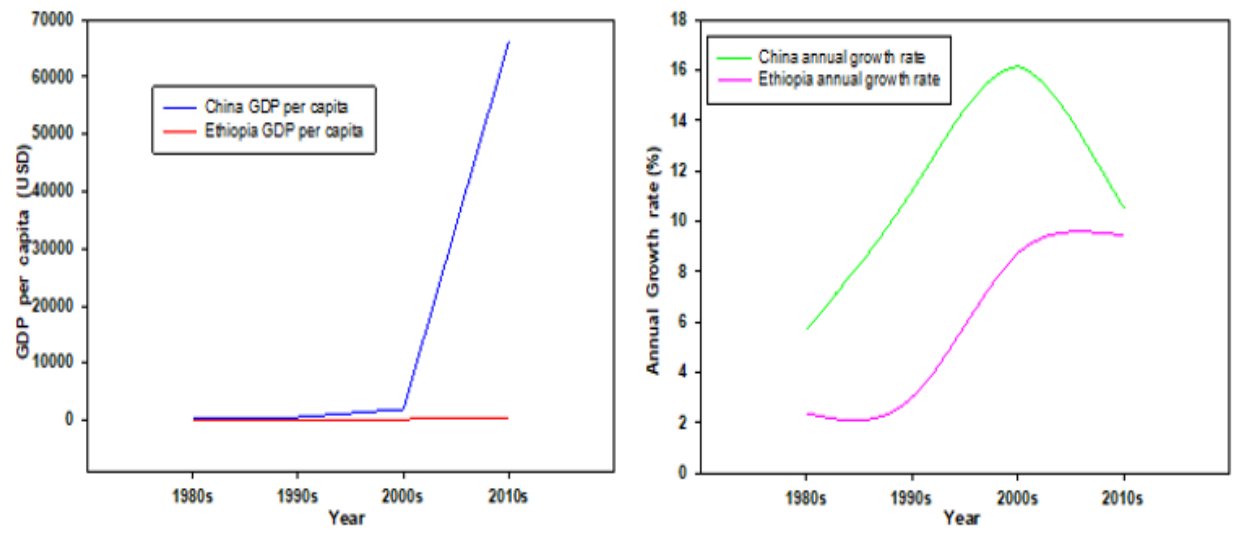

Figure 2 GDP per capita of China and Ethiopia (left Fig.) and Annual growth rate of the two countries (right Fig.). Source author computed from online World Bank data and www.macroternds.net

\section{CONCLUSION}

Sustainable agriculture involves social, economic, and environmental sustainability considerations. Even though the productivity in agriculture remains low in most developing countries due to the relative inefficiency of agriculture, the growth productivity has been viewed for a long time as a basis for the process of structural and economic growth. To meet the food security of each nation both China and Ethiopia have implemented different policies and action at different times. In China, land reform has created a fragmented agricultural land structure leading many individual farmers to have several small fields with distant locations. The fragmented land had affected the labor supply, technology in machinery use. To reduce the land fragmentation problems the country has launched different land consolidation projects that target the development and consolidation of scarred land for supplementing cultivated land as well as the integration of field, water, roads, forest, and village that finally leads the overall development of urban and rural areas. Like China, Ethiopia's land fragmentation causes different problems in the local areas such as higher costs leading to less efficiency, increase border disputes resulting in loss of land as a demarcation purpose, and hinders investment in the land like integrated soil and water conservation measures to enhance the soil fertility. To tackle the impacts of land fragmentation Ethiopian government has been motivating voluntary land consolidation for agricultural mechanization, improving labor productivity, enhancing transport facilities, better utilization of farm resources, reducing cost, and enhancing opportunities for private investment. Therefore, to meet food security and reduce the yield gap in Ethiopia the better infrastructure development that meets socio-economic demands should be prioritized while in China to minimize the environmental costs due to high agricultural inputs policies to reduce fertilizer inputs are highly recommended to sustain agriculture growth.

\section{REFERENCES}

Abebaw Andarge Gedefaw, Clement Atzberger, Walter Seher, and R. M. (2019) 'Farmers Willingness to Participate In Voluntary Land', MDPI, 8(148), pp. 121. DOI : doi :10.3390/land8100148. Retrieved from https://doi.org/10.3390/land8100148 
Alemu, G. T., Berhanie Ayele, Z. and Abelieneh Berhanu, A. (2017) 'Effects of Land Fragmentation on Productivity in Northwestern Ethiopia', Advances in Agriculture, 2017, pp. 1-9. DOI : 10.1155/2017/4509605. Retrieved from https://doi.org/10.1155/2017/4509605

Ali, D. A., Deininger, K., and Ronchi, L. (2019) 'Costs and Benefits of Land Fragmentation : Evidence from Rwanda', World Bank Economic Review, 33(3), pp. 750-771. DOI : 10.1093/wber/lhx019. Retrieved from https://doi.org/10.1093/wber/lhx019

Baye, T. G. (2018) 'Property Rights and Their Implications on Agricultural Productivity in Ethiopia: A History, 45(1). Retrieved from https://www.ajol.info/index.php/eje/article/view/181424

Belay, K. and Manig, W. (2004) 'Access to Rural Land in Eastern Ethiopia : Mismatch between Policy and Reality', Journal of Agriculture and Rural Development in the Tropics and Subtropics, 105(2), pp. 123-138. Retrieved from https://jarts.info/index.php/jarts/article/view/55

Bezabih, M., Kohlin, G. and Mannberg, A. (2011) 'Trust, tenure insecurity, and land certification in rural Ethiopia', Journal of Socio-Economics. Elsevier Inc., 40(6), pp. 833-843. DOI : 10.1016/j.socec.2011.08.015. Retrieved from https://doi.org/10.1016/j.socec.2011.08.015

Bruce, J. W., and Hoben, A. (1994) 'After the Derg : An assessment of rural land tenure issues in Ethiopia', (March).

Chang, H., Ai, P. and Li, Y. (2018) 'Land tenure policy and off-farm employment in rural China', IZA Journal of development and migration. IZA Journal of Development and Migration. DOI : 10.1186/s40176-017-0117-z. Retrieved from https://doi.org/10.1186/s40176-017-0117-z

Chekol, B. (2017) 'Contending views on land tenure system in Ethiopia: Historiographical essay', 9(January), pp. 1-6. DOI : 10.5897/AJHC2016.0335. Retrieved from https://doi.org/10.5897/AJHC2016.0335

Chen, X. et al. (2013) 'Modern maize hybrids in Northeast China exhibit increased yield potential and resource use efficiency despite adverse climate change', Global Change Biology, 19(3), pp. 923-936. DOI : 10.1111/gcb.12093. Retrieved from https://doi.org/10.1111/gcb.12093

Chen, X. et al. (2014) 'Producing more grain with lower environmental costs', Nature. Nature Publishing Group, 514(7253), pp. 486-489. DOI : 10.1038/nature13609. Retrieved from https://doi.org/10.1038/nature13609

Cheng, L. et al. (2015) 'Analysis of farmland fragmentation in China Modernization Demonstration Zone since " Reform and Openness" : A case study of South Jiangsu Province', Scientific Reports. Nature Publishing Group, 5(February), pp. 1-11. DOI : 10.1038/srep11797. Retrieved from https://doi.org/10.1038/srep11797

Chojnicki, Z. (2010) 'Socio-economic development and its axiological aspects', Quaestiones Geographical, 29(2), pp. 7-17. DOI : 10.2478/v10117-0100010-9. Retrieved from https://doi.org/10.2478/v10117-010-0010-9

Cholo, T. C. et al. (2018) 'Land fragmentation, climate change adaptation, and food security in the Gamo Highlands of Ethiopia', (June 2017), pp. 1-37. DOI : 10.1111/agec.12464. Retrieved from https://doi.org/10.1111/agec.12464

Cholo, T. C., and Fleskens, L. (20018) 'Is Land Fragmentation Facilitating or Obstructing Adoption of Climate Adaptation Measures in Ethiopia?', 


\section{Sustainability. DOI : 10.3390/su10072120. Retrieved from https://doi.org/10.3390/su10072120}

Crewett, W. and Korf, B. (2008a) 'Ethiopia : Reforming Land Tenure An Ideological Battlefield: Land Policy in Ethiopia', (116), pp. 203-220. DOI : 10.1080/03056240802193911. Retrieved from https://doi.org/10.1080/03056240802193911

Crewett, W. and Korf, B. (2008b) 'Review of African Political Economy Ethiopia: Reforming Land Tenure Ethiopia: Reforming Land Tenure', (December 2014), pp. 37-41. DOI : 10.1080/03056240802193911. Retrieved from https://doi.org/10.1080/03056240802193911

David Asante Edwin, Evam Kofi Glover, and E. K. G. (2020) 'When Tradition Meets Modernity in Land Registration : Evidence from Dagbon, Ghana', pp. 1-28.

Day, A. F., Schneider, M. and Day, A. F. (2017) 'The end of alternatives ? Capitalist transformation, rural activism and the politics of possibility in China', The Journal of Peasant Studies. Taylor \& Francis, 0(0), pp. 1-25. DOI : 10.1080/03066150.2017.1386179. Retrieved from https://doi.org/10.1080/03066150.2017.1386179

Deininger, K. and Jin, S. (2006) 'Tenure security and land-related investment: Evidence from Ethiopia', 50, pp. 1245-1277. DOI : 10.1016/j.euroecorev.2005.02.001. Retrieved from https://doi.org/10.1016/j.euroecorev.2005.02.001

Deininger, K. et al. (2008) 'Rural Land Certification in Ethiopia: Process, Initial Impact, and Implications for Other African Countries', World Development. Elsevier Ltd, 36(10), pp. 1786-1812. DOI : 10.1016/j.worlddev.2007.09.012. Retrieved from https://doi.org/10.1016/j.worlddev.2007.09.012

Dong, Z. et al. (2020) 'Landscape agricultural simplification correlates positively with the spatial distribution of a specialist yet negatively with a generalist pest', Scientific Reports, 10(1), pp. 1-9. DOI : 10.1038/s41598-019-570774. Retrieved from https://doi.org/10.1038/s41598-019-57077-4

Erwin Knippenberg, Dean Jolliffe, J. H. (2017) 'Land Fragmentation and Food Insecurity in', (July). Retrieved from https://doi.org/10.1596/1813-94508559

FAO and World Bank (2001) 'Farming Systems and Poverty, in Improving farmers' livelihoods in a changing world.

Gajendra S. Niroula, G. B. T. (2005) 'Impacts and causes of land fragmentation, and lessons learned from land consolidation in South Asia', 22, pp. 358-372. DOI : 10.1016/j.landusepol.2004.10.001. Retrieved from https://doi.org/10.1016/j.landusepol.2004.10.001

Ghose, B. (2014) 'Food security and food self-sufficiency in China : From past to 2050', Food and Energy Security, 3(2), pp. 86-95. DOI : 10.1002/fes3.48. Retrieved from https://doi.org/10.1002/fes3.48

Girum Getachew, Ezana Amdework, Larissa Stiem-Bhatia, and J. W. (2019) 'Opportunities for Voluntary Land Consolidation in Ethiopia: Farmers' Perspectives'. Retrieved from https://www.researchgate.net/profile/Larissa-Stiem-

Bhatia/publication/336718098_Opportunities_for_Voluntary_Land_Consol idation_in_Ethiopia_Farmers'_Perspectives/links/5daede5b4585155e27f7 c18f/Opportunities-for-Voluntary-Land-Consolidation-in-Ethiopia-

Farmers-Perspectives.pdf 
Hanjra, M. A., Ferede, T. and Gemechu, D. (2009) 'Reducing poverty in sub-Saharan Africa through investments in water and other priorities', 96, pp. 10621070. DOI : 10.1016/j.agwat.2009.03.001. Retrieved from https://doi.org/10.1016/j.agwat.2009.03.001

Headey, D., Dereje, M. and Seyoum, A. (2014) 'Land constraints and agricultural intensification in Ethiopia : A village-level analysis of high-potential areas', JOURNAL OF FOOD POLICY. Elsevier Ltd. doi: 10.1016/j.foodpol.2014.01.008. Retrieved from https://doi.org/10.1016/j.foodpol.2014.01.008

Heerink, N. et al. (2007) 'Policy reforms, rice production and sustainable land use in China : A macro-micro analysis', Agricultural Systems, 94(3), pp. 784-800. DOI : 10.1016/j.agsy.2006.11.005. Retrieved from https://doi.org/10.1016/j.agsy.2006.11.005

Hong, Y. (2008) 'Property rights and Land Policies'.

Hristov, J. (2009) 'Degree Thesis in Business Administration Uppsala', Business.

Huang, D. et al. (2017) 'How Do Differences in Land Ownership Types in China Affect Land Development? A Case from Beijing'. DOI : 10.3390/su9010123. Retrieved from https://doi.org/10.3390/su9010123

Huang, J. and Rozelle, S. (2009) 'Agricultural Development and Nutrition: the Policies behind China 's Success', (November).

Huang, J., Wang, X. and Qiu, H. (2012) Small-scale farmers in China in the face of modernization and globalization.

Industries, E. and Conservation, A. (2013) 'CHAPTER 2 Land tenure : industry, ape conservation, and communities Introduction', pp. 38-63.

JIAO, X., SHEN, J. and ZHANG, F. (2020) 'A potential solution for food security in Kenya : implications of the Quzhou model in China', Frontiers of Agricultural Science and Engineering, 7(4), pp. 406-417. DOI : 10.15302/J-FASE2020359. Retrieved from https://doi.org/10.15302/J-FASE-2020359

Jia, L. and Petrick, M. (2014) 'How does land fragmentation affect off-farm labor supply: Panel data evidence from China', Agricultural Economics (United Kingdom), 45(3), pp. 369-380. DOI : 10.1111/agec.12071. Retrieved from https://doi.org/10.1111/agec.12071

Kebede, B. (2002) 'Land Tenure and Common-Pool Resources in Rural Ethiopia : A Study Based on Fifteen Sites', (December 2000), pp. 113-149. Retrieved from https://doi.org/10.1111/1467-8268.00048

Kelly, A. B., and Peluso, N. L. E. E. (2015) 'Frontiers of Commodification : State Lands and Their Formalization', (March 2014), pp. 473-495. DOI : 10.1080/08941920.2015.1014602. Retrieved from https://doi.org/10.1080/08941920.2015.1014602

Lai, W., Roe, B. and Liu, Y. (2015) 'Estimating the Effect of Land Fragmentation on Machinery Use and Crop Production, Agricultural \& Applied Economics Association and Western Agricultural Economics Association Annual Meeting, San Francisco, CA, July 26-28. Retrieved from https://ageconsearch.umn.edu/record/205280/

Latruffe, L. and Piet, L. (2014) 'Does land fragmentation affect farm performance? A case study from Brittany, France', Agricultural Systems, 129(40), pp. 6880. DOI : 10.1016/j.agsy.2014.05.005. Retrieved from https://doi.org/10.1016/j.agsy.2014.05.005

Liu, Z. and Liu, L. (2016) 'Characteristics and driving factors of rural livelihood transition in the east coastal region of China: A case study of suburban 
Shanghai', Journal of Rural Studies. Elsevier Ltd, 43, pp. 145-158. DOI : 10.1016/j.jrurstud.2015.12.008. Retrieved from https://doi.org/10.1016/j.jrurstud.2015.12.008

Lohmar, B. et al. (2009) 'China ' s Ongoing Agricultural Modernization Challenges Remain After 30 Years of Reform Cataloging Record :', (51).

Ma, X. et al. (2015) 'Land Use Policy Farmland tenure in China: Comparing legal, actual and perceived security, Land Use Policy. Elsevier Ltd, 42, pp. 293-306. DOI : 10.1016/j.landusepol.2014.07.020. Retrieved from https://doi.org/10.1016/j.landusepol.2014.07.020

Mackenzie Valley (2007) 'Chapter 2 - Introduction to Socio-Economic Impact Assessment', Environmental Impact Review Board. Available at : Retrieved from http://www.reviewboard.ca/upload/ref_library/.

Maestas, N., Mullen, K. and Powell, D. (2016) 'The Effect of Population Aging on Economic Growth, the Labor Force and Productivity, The Effect of Population Aging on Economic Growth, the Labor Force and Productivity. DOI : 10.7249/wr1063-1. Retrieved from https://doi.org/10.7249/WR1063-1

Mccartney, L. and Lefsrud, M. G. (2018) 'Protected agriculture in extreme environments: A review of controlled environment agriculture in tropical, arid, polar and urban locations.', 34(2), pp. 455-473. Retrieved from https://doi.org/10.13031/aea.12590

Nations United (2019) World population prospects 2019, Department of Economic and Social Affairs. World Population Prospects 2019. Available at : Retrieved from http://www.ncbi.nlm.nih.gov/pubmed/12283219.

Nkurunziza, L. et al. (2020) 'Socio-ecological factors determine crop performance in agricultural systems, Scientific Reports, 10(1), pp. 1-12. DOI : 10.1038/s41598-020-60927-1. Retrieved from https://doi.org/10.1038/s41598-020-60927-1

OECD (2019) 'National Accounts of OECD Countries 2019, Volume I, Main Aggregates', OECD National Accounts Statistics. Available at : Retrieved from https://www.oecd-ilibrary.org/economics/national-accounts-of-oecdcountries-2009-volume-i-main-aggregates_na_vol_1-2009-en-fr.

Paul, M. and Gĩthĩnji, M. (2017) 'Small farms, smaller plots : land size, fragmentation, and productivity in Ethiopia', 6150(April). DOI : 10.1080/03066150.2016.1278365. Retrieved from https://doi.org/10.1080/03066150.2016.1278365

Peterson, E. W. F. (2017) 'The role of population in economic growth', SAGE Open, 7(4). DOI : 10.1177/2158244017736094. Retrieved from https://doi.org/10.1177/2158244017736094

Reynolds, T. W., Farley, J., and Huber, C. (2010) 'Investing in human and natural capital : An alternative paradigm for sustainable development in Awassa, Ethiopia', Ecological Economics. Elsevier B.V., 69(11), pp. 2140-2150. DOI : 10.1016/j.ecolecon.2009.03.007. Retrieved from https://doi.org/10.1016/j.ecolecon.2009.03.007

Savas, B. (2008) 'The relationship between Population and Economic growth: Empirical evidence from the central Asian economies', pp. 161-183.

Shen, Z. (2015) 'Analysis of the Correlation Between Population Growth and Economic Development in Asian Countries', Cross-Cultural Communication, 11(11), pp. 6-11. DOI : 10.3968/7899. 
Shi, L. and Vendryes, T. (2018) 'China Economic Review Real estate activity, democracy and land rights in rural China', (February 2016). DOI : 10.1016/j.chieco.2018.05.004. Retrieved from https://doi.org/10.1016/j.chieco.2018.05.004

Sihem, E. (2019) 'Economic and socio-cultural determinants of agricultural insurance demand across countries, Journal of the Saudi Society of Agricultural Sciences. King Saud University, 18(2), pp. 177-187. DOI : 10.1016/j.jssas.2017.04.004. Retrieved from https://doi.org/10.1016/j.jssas.2017.04.004

Sun, Z., You, L. and Müller, D. (2018) 'Synthesis of agricultural land system change in China over the past 40 years', Journal of Land Use Science. Taylor \& Francis, 13(5), pp. 473-479. DOI : 10.1080/1747423X.2019.1571120. Retrieved from https://doi.org/10.1080/1747423X.2019.1571120

Sun, Z., You, L. and Müller, D. (2019) 'Synthesis of agricultural land system change in China over the past 40 years Synthesis of agricultural land system change in China over the', Journal of Land Use Science. Taylor \& Francis, 00(00), pp. 1-7. DOI : 10.1080/1747423X.2019.1571120. Retrieved from https://doi.org/10.1080/1747423X.2019.1571120

Tan, S., Heerink, N. and Qu, F. (2006) 'Land fragmentation and its driving forces in China', Land Use Policy, 23(3), pp. 272-285. DOI : 10.1016/j.landusepol.2004.12.001. Retrieved from https://doi.org/10.1016/j.landusepol.2004.12.001

Vendryes, T. and Vendryes, T. (2019) 'Land Rights in Rural China since 1978'.

Wibke Crewett, Ayalneh Bogale, and B. K. (2008) 'Land Tenure in Ethiopia Continuity and Change Shifting Rulers, and the Quest for State Control', (91). Retrieved from https://ageconsearch.umn.edu/record/50890/

Yan, J., Xia, F., and Bao, H. X. H. (2015) 'Strategic planning framework for land consolidation in China : A top-level design based on SWOT analysis', Habitat International, 48(44), pp. 46-54. DOI : 10.1016/j.habitatint.2015.03.001. Retrieved from https://doi.org/10.1016/j.habitatint.2015.03.001

Yang, B. et al. (2020) 'Analyzing land use structure efficiency with carbon emissions: A case study in the Middle Reaches of the Yangtze River, China', Journal of Cleaner Production. Elsevier Ltd, 274, p. 123076. DOI : 10.1016/j.jclepro.2020.123076. Retrieved from https://doi.org/10.1016/j.jclepro.2020.123076

Zeng, S. et al. (2018) 'Assessing the impacts of land consolidation on agricultural technical efficiency of producers: A survey from Jiangsu Province, China', Sustainability (Switzerland), 10(7), pp. 9-11. DOI : 10.3390/su10072490. Retrieved from https://doi.org/10.3390/su10072490

Zhang, B. X. (2016) 'Land Reallocation in Land Consolidation : A Chinese Model and Its Future Direction', (May 2016), pp. 1-15. Retrieved from https://pdfs.semanticscholar.org/2072/817d4760eb8459c356399c7bdb3 ca439b03f.pdf

Zhang, J. (2011) 'China's success in increasing per capita food production, Journal of Experimental Botany, 62(11), pp. 3707-3711. DOI : 10.1093/jxb/err132. Retrieved from https://doi.org/10.1093/jxb/err132

Zhang, R., Gao, M. and Wang, H. (2018) 'General Strategy of Land Consolidation in China', IOP Conference Series: Earth and Environmental Science, 199(2). DOI : 10.1088/1755-1315/199/2/022068 Retrieved from https://doi.org/10.1088/1755-1315/199/2/022068 